\title{
Iranian EFL Teachers' Perspectives on SLA Research and EFL Pedagogy: Do Majors Matter?
}

\author{
Fatemeh Soltanpour (Corresponding author) \\ English Department, Kar Higher Education Institute, PO Box 1571, Qazvin, Iran \\ E-mail: fatemeh.soltanpour@yahoo.com \\ Mohammadreza Valizadeh \\ English Department, Faculty of Foreign Languages, Gazi University, PO Box 06500, Ankara, Turkey \\ E-mail: mrvalizadeh2015@gmail.com
}

\author{
Received: 15-02-2017 \\ Accepted: 07-04-2017 \\ Advance Access Published: July 2017 \\ Published: 01-09-2017 \\ doi:10.7575/aiac.ijalel.v.6n.5p.90 \\ URL: http://dx.doi.org/10.7575/aiac.ijalel.v.6n.5p.90
}

\begin{abstract}
Considering the issues of EFL (English as a Foreign Language) teacher education, recruitment, and supervision system in Iran, this study investigated the Iranian EFL teachers' familiarity, involvement with, accessibility to, and their judgments about usefulness of SLA (Second Language Acquisition) research. The sources the teachers consult about teaching and SLA research were also explored. Moreover, the mentioned issues were explored in terms of the teachers' majors in order to find any significant associations between the teachers' majors and the raised issues or any significant differences between the two participating groups of teachers' perspectives in the above-mentioned subjects. Quantitative data were collected through a questionnaire. 142 participating Iranian EFL teachers were divided into two groups of TEFL (Teaching English as a Foreign Language) and Non-TEFL majors based on their university degrees and their opinions were compared. Significant associations were found between the teachers' majors and their familiarity with and their access to SLA research and materials. Moreover, significant differences were found between the opinions of two groups of teachers about the relevance and usefulness of SLA research for classroom teaching as well as two of the items under the topic of teacher-researcher relationship. However, both groups of the Iranian EFL teachers seemed to be willing to cooperate with the SLA researchers and no significant difference was revealed between them. To improve the condition, creating a culture of collaboration as well as the amending of the language teacher education programs and supervision system are vital steps to be taken in Iran.
\end{abstract}

Keywords: Second language acquisition (SLA) research, SLA research and EFL pedagogy in Iran, EFL teacher education and supervision, Iranian EFL teachers' majors and perspectives

\section{Introduction}

Considering the context of Iran, as Dahmardeh (2009) stated, language has been neglected within the Iranian educational system though it is a compulsory academic subject in the Iranian national curriculum. Atai and Mazlum's (2013) investigation revealed "the lack of any ELT-specific document for material development and absence of research-based needs assessment as the foundation of the programs" (p. 389). According to them,

There are no pre-defined linguistic and professional criteria for evaluating teachers, and planning for students' assessment is limited to a set of general guidelines. Moreover, there is neither a programme evaluation nor an ELT evaluation model and national-level policies are not re-examined at planning level. ... Politico-ideological beliefs of material developers are as important as their expertise and communication channels between planning and practice levels are of a top-down nature. It is argued that the gap between planning and practice results from a highly centralised policymaking process in which local policymakers (i.e. teachers) are not involved. (p. 389)

Likewise, Davari and Aghagolzadeh (2015) stated, neither English nor any other foreign language teaching academic settings in Iran have received much attention until recently and no formal document in English language policy, whether national or educational, has been developed or implemented, yet.

What inspired the researchers of this study to conduct this research was, at first, the issue of EFL teacher recruitment in Iran. To teach English in Iranian public and private schools and private institutes, being certified in TEFL (Teaching English as a Foreign Language) is not a must. Not only the English university students, graduates, and postgraduates with specialization in TEFL, English Literature, Translation Studies, (Moghaddas \& Zakeri, 2012) and Theoretical Linguistics, but also those whose majors are not relevant to English at all and have never passed any creditable TEFL courses, yet have impressive command of English, are teaching in English language institutes in Iran (Karimi, 2011). As Karimi (2011, p. 90) stated, most of the courses the teachers who are majored in English-related fields other than TEFL "have passed during their studies have been subject matter rather than pedagogical courses. They have, however, had a minimal number of courses on EFL instruction." Talebinejad and Moattarian $(2015$, p. 7) found, "teachers in language 
institutes are mostly selected based on their knowledge of general English, not specialized knowledge in SLA or applied linguistics." Mohsenian, Rezai, and Abdolmanafi-Rokni (2015) found that general English skills and especially the speaking skill were the most important criterion in teacher selection for the Iranian managers of 100 private English institutes. The criteria of Academic Degree or Authentic Teaching Certificate, which were grouped under the title of Degree factor, stood fourth in the ranking of the importance of each criterion for determining whether or not a teacher was qualified enough to be employed; the issues of innovation and creativity stood sixth in the ranking and were considered less important than the factor of appearance. In addition, according to Akbari \& Yazdanmehr (2011), the majority of the Iranian teachers only pass an intensive Teacher Training Course (TTC) in which they only get familiar with the dominant approach or methodology adopted by the institute. Moreover, Karimvand, Hessamy, and Hemmati (2014) stated that the lengths of some of the TTCs are as short as three or four sessions; such length is insufficient to cover all ELT (English Language Teaching) issues.

In addition, unfortunately, the condition of the current in-service EFL Teacher Education program in Iran is not satisfying in terms of improving English teachers' language proficiency level, teaching skills, management skills, and evaluation skills (Beh-Afarin, 2003; Razi \& Kargar, 2014). The following points have been indicated by the specialists:

$>$ In Iran, EFL teacher education has a mainly positivistic and transmission-oriented approach in which the prospective teachers are mainly passive recipients of deposits of pre-selected knowledge transferred by their trainers. (Farhady, Sajadi, \& Hedayati, 2010; Jadidi \& Bagheri 2014; Karimvand, et al, 2014). In such courses, there is no opportunity for critical reflection (Farrell, 2007, as cited in Karimvand, et al). Creativity has no place in such courses, either, even though it has been proved that fostering creativity is very beneficial and can improve teachers' ability to provide learning experiences (Montgomery, 1997).

$>$ Many teacher educators usually do not encourage prospective teachers to actively participate in the process of learning to teach and, instead, spend the courses giving lectures. They mainly require the student teachers to take notes and memorize the materials presented in the class (Nezakat-Alhossaini \& Ketabi, 2010; Karimvand, et al, 2014). This is against the constructivist principle that adults learn best when provided with the opportunity to make their own choices and change them if needed. As a result, under such conditions, the results can be poor and disappointing. The importance of collaborative reflection among teachers has been proved (Fernandez-Balboa \& Marshall, 1994) and recommended (Ellis, 2010); however, such collaboration does not exist in teacher training courses in Iran.

$>$ The content of many teacher training programs implemented in EFL institutes is mainly theoretical and decontextualized (Farhady et al, 2010; Sarlak \& Vafaeimehr's 2014), so the teachers believe the contents of the in-service teacher education programs are different from the reality of the actual classroom situations and thus not applicable in the real classrooms (Mohammadi, Karimian \& Talebinejad 2015) although the scholars had emphasized an urgent need for a more practical approach including social and cultural considerations (Akbari, 2008; Farhady et al, 2010).

$>$ In many cases, the teacher trainers do not assess the prospective teachers' real ability by a practical test and the tests are mainly summative and objective (Farhady et al., 2010; Maftoon, Yazdani, Gholebostan, \& Beh-Afarin, 2010; Nezakat-Alhossaini \& Ketabi, 2010).

$>$ The length of some of the TTCs is as short as three or four sessions which is insufficient to cover all ELT issues (Karimvand et al 2014)

Moreover, as it was reported by Rahmany, Hasani, and Parhoodeh (2014, p. 348-349),

In some institutes and English Language Centers, there is no observation system and the teachers (especially novice teachers) are faced with many problems in classes while they have passed TTC. In some other institutes ..., [supervision] is restricted to a paperwork job rather than a tool for teaching and hence learning improvement. Some other institutes have based their supervision practice on traditional theories of supervision in which the teacher has no role and his creativity and independence are mostly ignored.

The participating Iranian EFL teachers in Moradi, Sepehrifar, and Parhizkar Khadiv's (2014) study believed that supervision is not able to guide teachers in finding solutions to their problems in the classroom. In fact, supervision is an inspection rather than a collaborative process, revealing that the relationship between the teachers and supervisor is based on a hierarchical structure in which the supervisors dominate the whole process and exercise their own power and authority over teachers; thus, there is not a friendly appropriate atmosphere for involvement and collaboration in real sense. Teachers try to please their supervisors because, in effect, they are concerned about the unpleasant consequences of getting the 'unsatisfactory' rating by supervisors and even being fired. Moradi et al (2014) were surprised to see that although supervision is supposed to be an important element of in-service training for the professional development of teachers, it serves to decrease teachers' motivation and confidence. This was also revealed by Navidinia, Kiani, Akbari, and Ghafar Samar (2014).

Considering all the above-mentioned issues, the subject of the relationship between SLA research and L2 teaching comes to mind. Although the stated relationship is not a straightforward one (Nassaji, 2012), improving L2 teaching has been one of the key rationales for carrying out SLA research (Larsen-Freeman, 1998); however, some researchers (e.g., Block, 2000; Crookes, 1993; Klein, 1998) have been concerned about the degree to which the SLA research has actually influenced L2 teaching. Different reasons have been pinpointed for this problem. For example, Ellis (1997b, 2001, both cited in Nassaji, 2012) said that teachers' goal is to develop practical knowledge while SLA researchers have been interested in developing technical knowledge. Another problem stems from the difference between the teachers' 
discourse and SLA researchers' one (Bartels, 2003; Ellis, 1997). Ellis (1997) stated that because teachers and researchers "represent different social worlds with different values, beliefs, and attitudes" (p. 72), there is a potential conflict between the discourses of SLA and language teaching. Bartels (2003) said that by communicating research findings, researchers want to reach abstract and generalizable knowledge, but teachers' aim of reading and communicating such findings is to develop practical knowledge which is specific to their own context.

As Nassaji (2012) assured, "Although there are concerns about the relevance of SLA research to language teaching, there are currently an increasing number of SLA studies in the field that have important relevance to language teaching." (p. 340). For more examples, see Nassaji (2012). Scholars have argued that teachers who are familiar with and consult SLA research about their teaching benefit greatly. For instance, Larsen-Freeman (1998) stated,

Teachers who have been exposed to concepts and research in SLA courses ... often become more learningcentered. The benefit of this shift is twofold: Their responses to their students are more relevant, and their own professional development is ensured, for becoming fascinated with what learners do is an excellent way of keeping one's teaching practice vital. (p. 554)

Moreover, research done by teachers themselves, named teacher research, action research, practitioner research or exploratory practice (Allwright, 2005) is known as a tool to promote professional development (e.g. Crookes, 1993; Crookes \& Chandler, 2001; Norton, 2009; Nunan, 1997; Somekh, 2006). Richards and Farrell (2005, p. 173) also stated that "teachers who have carried out action research often report significant changes to their understanding of teaching." With regard to the stated background, the issue of what teachers know about L2 research or how they view its usefulness for their teaching is very important. Nevertheless, as Nassaji (2012) said, little empirical research has been conducted into it. On the other hand, in light of the mentioned background in Iran, the researchers in this study believe that in such circumstances in Iran, the EFL teachers who have only passed an intensive TTC or those who have not studied any courses on SLA or Research Methods could be markedly different from those who have studied TEFL in terms of their familiarity, involvement with, accessibility to, and expectations of SLA research as well as their judgments about usefulness of such research. Therefore, we have decided to investigate this issue in order to contribute to improving the relationship between SLA research and language pedagogy in Iran. All in all, the following research questions have been addressed:

1. To what extent are Iranian EFL teachers familiar with SLA research? Is there a significant association between the teachers' majors and their familiarity with the issue?

2. Is there a significant difference between the two groups of teachers' ideas about the usefulness of courses on SLA and research methods?

3. Is there a significant association between the teachers' majors and their access to the SLA research as well as the sources they consult?

4. Is there a significant association between the teachers' majors and their reasons for not reading research articles?

5. Is there a significant difference between the two groups of teachers considering the frequency of their reading research articles?

6. What percentage of the teachers in each group has already conducted research on SLA? What reasons do they provide for not carrying out the research? Is there a significant association between the teachers' majors and their reasons? Do teachers receive any support to do research on SLA at their institute?

7. How do they judge the relevance and usefulness of SLA research for classroom teaching? Is there a significant difference between the two groups of teachers in their judgments?

8. How do they perceive the relationship between researchers and teachers? Is there a significant difference between the two groups of teachers in their perception of the raised issue?

\section{Literature Review}

Samar, Mehrani, and Kiyani (2013) studied the generalizability of the findings of quantitative research studies in Iranian ELT context. Considering the research subjects' age and the research sites, it appeared that although the Iranian EFL learners who are not university students and are learning English at schools or private institutes vastly outnumber the university students, more than $60 \%$ of previous research had been conducted in academic settings and on university students. About $20 \%$ of the studies had focused on language learners in private language institutes and students in junior and senior high schools. Pre-university centers had been investigated in only $7 \%$ of previous studies. Therefore, the imbalanced focus of previous studies can impose a problem on the generalizability of previous ELT studies. In addition, it was found that English teachers at schools as well as private institutes were not highly focused on; only $6 \%$ of the previous studies in Iran focused on these two groups of teachers though they have principal roles in the process of language teaching and learning. Samar and his colleagues offered some convincing reasons for the mentioned neglect of school students: (1) There is a total lack of constructive relationship and communication between the universities and schools (Samar et al, 2013, as cited from Mehrdad \& Rastkhaneh 1380, a Persian article), (2) There is a lack of motivation among the school teachers to participate in university research (Samar et al, 2013, as cited from Rajabi, 1380, a Persian article), (3) Only one of the language skills - Reading - is taught in schools under the control of the Ministry of Education, and (4) It takes a very long time to coordinate the research project with the school principals.

In addition, Mehrani and Behzadnia's (2013) qualitative data via the interview with 23 Iranian English teachers revealed low levels of engagement in terms of reading and doing research. Furthermore, they found barriers related to the production of research, use of research, lack of collaboration between researchers and practitioners, as well as barriers 
related to the educational system.

Moreover, Mehrani (2014) studied the strategies that could be potentially adopted in the Iranian ELT context to improve the relationship between researchers and practitioners. He found that both Iranian teachers and researchers need to be encouraged toward doing evidence-based teaching and problem-based research. In addition, to reduce the gap between research and practice, developing professional and social networks, founding an organization for promoting collaboration and cooperation between researchers and practitioners, supporting the involvement of teachers in academic activities, and revising and updating the currently used educational materials, which have been used for more than 30 years in Iranian schools, are of crucial importance. The teachers emphasized that if they are supposed to be research-oriented, a totally new teacher evaluation system needs to be designed and implemented in Iran. The teachers also criticized the current teacher education programs in Iran. They argued that lack of ability is the teachers' reason for not finding, reading, evaluating, and using research papers.

Besides, Mehrani's (2015) qualitative interviews with 24 teachers from both public school and private institutes indicated the teachers' moderate level of research engagement. He also found that teachers' professional development and pedagogical concerns, instrumental incentives and organizational expectations were the motivations for their research engagement. However, Mehrani concluded that such engagement will not happen if the teachers' working conditions in Iranian schools and policy conditions in the national education system are not changed.

Furthermore, Talebinejad and Moattarian's (2015) semi-structured interviews with 10 language teachers indicated that the teachers who had studied in graduate levels and the ones who had taught at university level appreciated the value of research more than the others. They believed that such positive attitude was because of the university environment and not language institutes. Furthermore, more experienced teachers were more interested in applying SLA research findings in their teaching practice than less experienced ones. However, they did not consult bodies of research in their teaching practice because it was not possible to apply the findings of SLA research in their classes due to (1) lack of knowledge in analyzing research articles, (2) lack of time, and (3) lack of facilities. In addition, the participating teachers believed that in the present situation, using SLA research findings in not practical. Their reasons included (1) Teacher Training Courses in Iran, (2) Teachers' employment, (3) Supervisors' ideologies and Classroom observation, (4) Top-down syllabus in which teachers do not have a leading role in syllabus design, (5) Selected materials, and (6) Teachers' knowledge and motivation.

Considering the previous studies, it can be argued that a good professional relationship between SLA research and language pedagogy has not been fostered in Iran. Besides, in each above-mentioned research, only the qualitative data was collected through interviews with less than 25 English teachers. Consequently, this issue needs further investigation, which can lead to proposing and hopefully adopting some practical solutions.

\section{Method}

This study has quantitative approach and is a cross-sectional design. Quantitative data were collected by means of the questionnaire which had been published in Nassaji's (2012) paper. The questionnaire had already been piloted and validated; nonetheless, it was distributed among a group of 10 Iranian EFL teachers. They were asked to answer the questions, offer constructive feedback on the wording and clarity of the items. No question was found as vague or difficult to understand. Consequently, no change was made to the original questionnaire, except the omission of the final open-ended questions for the qualitative inquiries which were not the focus of this study.

\subsection{Participants}

The questionnaires were distributed via e-mail or through personal contact to 183 EFL teachers. Their participation was voluntary. They were informed if they were willing to participate, they could fill out the questionnaire and turn it in at their earliest convenience, so by completing and returning the questionnaire, they would consent to take part in the study. 142 teachers filled out the questionnaire anonymously and returned them. 63 of them were certified in TEFL, so they were called TEFL Majors, but 79 respondents were certified in Non-TEFL majors, so they were named, Non-TEFL Majors. The majority of the participants were the teachers in private institutes. Only 11 respondents $(7.7 \%)$ were the public school teachers. Among the Non-TEFL majors, nine teachers (11.4\%) were not certified in any branches of English, but had passed an intensive TTC in the institute they were teaching. Tables 1 and 2 show the participating teachers' background information.

Table 1. Teachers' background information

\begin{tabular}{lccc}
\hline & & TEFL & Non-TEFL \\
\hline Age & Mean & 32.48 & 30.03 \\
& SD & 5.775 & 4.543 \\
Years of Teaching Experience & Mean & 9.51 & 7.30 \\
& SD & 4.662 & 4.062 \\
Gender & Female & $92.1 \%$ & $82.3 \%$ \\
& Male & $7.9 \%$ & $17.7 \%$ \\
Highest Degree Completed & BA & $19.0 \%$ & $58.2 \%$ \\
& MA & $73.0 \%$ & $39.2 \%$ \\
\hline
\end{tabular}




\begin{tabular}{lccc}
\hline Table 2. Teachers' additional teaching certificate & & \\
\hline Major & $\begin{array}{c}\text { Additional Teaching } \\
\text { Certificate (\%) }\end{array}$ & $\begin{array}{c}\text { International ELT } \\
\text { Certificates (\%) }\end{array}$ & $\begin{array}{c}\text { Iranian institute's TTC } \\
\text { Certificate (\%) }\end{array}$ \\
\hline & 31.1 & & \\
TEFL & 46.2 & 15.8 & 84.2 \\
Non-TEFL & 5.6 & 94.4 \\
\hline
\end{tabular}

\section{Analyses and Results}

Quantitative analyses were conducted on the data collected through close-ended questionnaire. In all the tables, the valid percent are mentioned. In addition, according to Field (2013), the assumption of normality was empirically tested through the ratio of skewness and kurtosis over their respective standard errors. Field said if the outcomes were within the ranges of $+/-1.96$, the data would enjoy normal distribution. Moreover, the effect size was interpreted based on Cohen (1988) as cited in Pallant (2013).

\subsection{Teachers' Familiarity with SLA Research}

In TEFL group, $93.5 \%$ and in Non-TEFL one, $64.6 \%$ had taken courses in L2 research methods. As the $p$-value was smaller than .05 , the chi-square test indicated a significant association between the teachers' majors and the issue of taking courses in L2 research methods, $(\mathrm{n}=141) x^{2}=15.03, d f=1, p=.00$. The effect size of the relationship was $p h i=.34$, meaning the effect of the major has a medium-to-large effect size on whether the teachers had taken courses in L2 research methods

In TEFL group, $93.4 \%$ and in Non-TEFL one, $61 \%$ had taken courses in SLA. As the $p$-value was smaller than .05 , the chi-square test indicated a significant association between the teachers' majors and the issue of taking courses in SLA, $(\mathrm{n}=138) x^{2}=17.54, d f=1, p=.00$. The value of phi equaled .37 , meaning the effect of the major has a medium-to-large effect size on whether the teachers had taken courses in SLA.

In TEFL group, $75.8 \%$ and in Non-TEFL one, $26.9 \%$ had conducted research. As the $p$-value was smaller than .05 , the chi-square test indicated a significant association between teachers' majors and the variable of conducting research, $(\mathrm{n}=140) x^{2}=31.11, d f=1, p=.00$. The value of phi was .48 , meaning the effect of the major has a large effect size on whether the teachers had conducted research.

In TEFL group, $41.3 \%$ and in Non-TEFL one, $2.8 \%$ had already published research. As the $p$-value was smaller than .05, the chi-square test indicated a significant association between the teachers' majors and the variable of publishing research, $(\mathrm{n}=135) x^{2}=27.98, d f=1, p=.00$. The phi value was .47 , meaning the effect of the major has a large effect size on whether the teachers had published research.

4.2 Difference between the two Groups of Teachers' Ideas about the Usefulness of Courses on SLA and Research Methods

The teachers who had already taken courses on SLA and research methods were asked to what extent they found them useful. Table 3 shows their responses.

Table 3. Usefulness of SLA courses

\begin{tabular}{|c|c|c|c|c|c|c|c|c|}
\hline & \multicolumn{2}{|c|}{ Very Useful } & \multicolumn{2}{|c|}{ Useful } & \multicolumn{2}{|c|}{ Somewhat Useful } & \multicolumn{2}{|c|}{ Not Useful } \\
\hline & Freq. & $\%$ & Freq. & $\%$ & Freq. & $\%$ & Freq. & $\%$ \\
\hline \multicolumn{9}{|c|}{ a) Courses on SLA } \\
\hline TEFL & 11 & 19.3 & 30 & 52.6 & 16 & 28.1 & 0 & 0 \\
\hline Non-TEFL & 11 & 23.4 & 25 & 53.2 & 11 & 23.4 & 0 & 0 \\
\hline
\end{tabular}

\begin{tabular}{lcccccccc}
\hline \multicolumn{2}{l}{ b) Courses on Research Methods } \\
\hline TEFL & 13 & 22.4 & 21 & 36.2 & 21 & 36.2 & 3 & 5.2 \\
Non-TEFL & 18 & 35.3 & 15 & 29.4 & 15 & 29.4 & 3 & 5.9
\end{tabular}

As Table 3 shows, regarding courses in SLA, 71.9\% of the TEFL majors and $81.6 \%$ of the Non-TEFL ones, found the course useful or very useful. With regard to courses in research methods, the statistics indicated $58.6 \%$ and $68.3 \%$ for the TEFL and Non-TEFL groups, respectively. Then, the teachers' ideas were compared with each other to find any significant differences between them. 
Table 4. Normality for the teachers' opinions about usefulness of courses

\begin{tabular}{|c|c|c|c|c|c|c|}
\hline \multicolumn{7}{|c|}{ Courses on Research Methods } \\
\hline & \multicolumn{3}{|c|}{ Skewness } & \multicolumn{3}{|c|}{ Kurtosis } \\
\hline & Statistic & Std. Error & Normality & Statistic & Std. Error & Normality \\
\hline TEFL & .009 & .314 & .02 & -.834 & .618 & -1.34 \\
\hline Non-TEFL & .321 & .333 & .96 & -1.028 & .656 & -1.56 \\
\hline \multicolumn{7}{|c|}{ Courses on SLA } \\
\hline TEFL & -.115 & .316 & -.36 & -.828 & .623 & -1.32 \\
\hline Non-TEFL & .000 & .347 & 0 & -.824 & .681 & -1.20 \\
\hline
\end{tabular}

As Table 4 indicates, the departure from normality was not too extreme. Therefore, two independent t-tests were run to compare the mean scores of the TEFL and Non-TEFL groups in order to find out whether there were any differences between the two groups of teachers' ideas about the usefulness of courses on SLA and research methods.

Table 5. Descriptive statistics about the usefulness of courses on research methods

\begin{tabular}{lllll}
\hline Group & $\mathrm{N}$ & Mean & SD & SEM \\
\hline TEFL & 58 & 2.24 & .865 & .114 \\
Non-TEFL & 51 & 2.06 & .947 & .133 \\
\hline
\end{tabular}

Table 6. Independent t-test for usefulness of courses on research methods

\begin{tabular}{|c|c|c|c|c|c|c|c|c|c|}
\hline & \multicolumn{2}{|c|}{$\begin{array}{c}\text { Levene's Test } \\
\text { for Equality of } \\
\text { Variances }\end{array}$} & \multicolumn{7}{|c|}{ t-test for Equality of Means } \\
\hline & \multirow[t]{2}{*}{$\mathrm{F}$} & \multirow[t]{2}{*}{ Sig. } & \multirow[t]{2}{*}{$\mathrm{t}$} & \multirow[t]{2}{*}{$\mathrm{df}$} & \multirow[t]{2}{*}{$\begin{array}{l}\text { Sig. (2- } \\
\text { tailed) }\end{array}$} & \multirow[t]{2}{*}{ Mean Difference } & \multirow[t]{2}{*}{$\begin{array}{l}\text { Std. Error } \\
\text { Difference }\end{array}$} & \multicolumn{2}{|c|}{$\begin{array}{c}95 \% \text { Confidence } \\
\text { Interval } \\
\end{array}$} \\
\hline & & & & & & & & Lower & Upper \\
\hline $\begin{array}{ll}\text { Equal } & \text { variances } \\
\text { assumed } & \end{array}$ & .29 & .58 & 1.05 & 107 & .29 & .18 & .17 & -.161 & .527 \\
\hline $\begin{array}{l}\text { Equal variances not } \\
\text { assumed }\end{array}$ & & & 1.04 & 102.07 & .29 & .18 & .17 & -.164 & .529 \\
\hline
\end{tabular}

As Table 6 indicates, the assumption of homogeneity of variances was met (Levene's $\mathrm{F}=.29, p=.29>.05$ ). That is why the first row of Table 6 "Equal variances assumed" is reported (Pallant, 2013). Based on the results displayed in Tables 5 and 6, it could be concluded that the difference between the two groups of teachers' opinions about the usefulness of courses on research methods was not significant $(\mathrm{t}(107)=1.05, p<.05)$; the $p$-value for this $\mathrm{t}$ was .29 (Sig(2tailed $)=.29>.05)$; it represented a large-sized effect $(\mathrm{r}=.10)$.

Table 7. Descriptive statistics about the usefulness of courses on SLA

\begin{tabular}{lllll}
\hline Group & $\mathrm{N}$ & Mean & SD & SEM \\
\hline TEFL & 57 & 2.09 & .689 & .091 \\
Non-TEFL & 47 & 2 & .692 & .101 \\
\hline
\end{tabular}

Table 8. Independent t-test for usefulness of courses on SLA

\begin{tabular}{|c|c|c|c|c|c|c|c|c|c|}
\hline & \multicolumn{2}{|c|}{$\begin{array}{c}\text { Levene's Test } \\
\text { for Equality of } \\
\text { Variances } \\
\end{array}$} & \multicolumn{7}{|c|}{ t-test for Equality of Means } \\
\hline & \multirow[t]{2}{*}{$\mathrm{F}$} & \multirow[t]{2}{*}{ Sig. } & \multirow[t]{2}{*}{$\mathrm{t}$} & \multirow[t]{2}{*}{$\mathrm{df}$} & \multirow[t]{2}{*}{$\begin{array}{l}\text { Sig. (2- } \\
\text { tailed) }\end{array}$} & \multirow[t]{2}{*}{ Mean Difference } & \multirow[t]{2}{*}{$\begin{array}{l}\text { Std. Error } \\
\text { Difference }\end{array}$} & \multicolumn{2}{|c|}{$\begin{array}{l}\text { 95\% Confidence } \\
\text { Interval }\end{array}$} \\
\hline & & & & & & & & Lower & Upper \\
\hline $\begin{array}{ll}\text { Equal } & \text { variances } \\
\text { assumed } & \end{array}$ & .21 & .64 & .64 & 102 & .52 & .08 & .13 & -.182 & .357 \\
\hline $\begin{array}{l}\text { Equal variances not } \\
\text { assumed }\end{array}$ & & & .64 & 98.10 & .52 & .08 & .13 & -.182 & .358 \\
\hline
\end{tabular}


Table 8 indicates that the assumption of homogeneity of variances was met (Levene's $\mathrm{F}=.21, p=.21>.05$ ), so the first row of Table 8, "Equal variances assumed" is reported (Pallant, 2013). Based on the results displayed in Tables 7 and 8 , the difference between the two groups of teachers' ideas about the usefulness of courses on SLA was not significant $(\mathrm{t}(102)=.64, \mathrm{p}<.05)$; the $p$-value for this $\mathrm{t}$ was $.52(\operatorname{Sig}(2$-tailed $)=.52>.05)$; it represented a moderate effect $(\mathrm{r}=.06)$.

\subsection{Accessibility of SLA Research, Sources Teachers Consult}

35 out of 63 TEFL majors (55.6\%) and 62 out of 79 Non-TEFL ones (78.5\%) stated they could access readings on SLA research. The chi-square test indicated a significant association between the teachers' majors and their access to such materials, $(\mathrm{n}=142), x^{2}=7.48, d f=1, p=.00<.05$. However, the phi value was -.24 , meaning the effect of the major has a nearly medium effect size on whether the teachers' access to readings on SLA research.

Table 9. Sources teachers consult

\begin{tabular}{lcccc}
\hline & \multicolumn{2}{c}{ TEFL } & \multicolumn{2}{c}{ Non-TEFL } \\
\hline & Freq. & $\%$ & Freq. & $\%$ \\
\hline a) about Research & & & & \\
\hline Books & 18 & 52.9 & 46 & 75.4 \\
Online Journals & 16 & 47.1 & 20 & 32.8 \\
Internet & 30 & 88.2 & 55 & 90.2
\end{tabular}

\begin{tabular}{lcccc}
\hline b) about Teaching & & & & \\
\hline Talking to colleagues & 39 & 61.9 & 60 & 75.9 \\
Reading journal articles & 56 & 88.9 & 25 & 31.6 \\
Doing empirical research & 12 & 19 & 6 & 7.6 \\
Reading books & 51 & 81 & 40 & 50.6 \\
Attending conferences \& workshops & 28 & 44.4 & 21 & 26.6
\end{tabular}

Note: Total percentages are greater than 100, which is due to multiple responses.

The following chi-square tests found no significant association between the teachers' majors and consulting online journals as well as the Internet. However, there was a significant association between the majors and consulting the books. In all variables, $d f$ equaled 1 .

Books: $(\mathrm{n}=95), x^{2}=4.04, p=.04, p h i=.23$

Online journals: $(\mathrm{n}=95), x^{2}=1.33, p=.24, p h i=-.14$

Internet: $(\mathrm{n}=95), x^{2}=.00, p=1, p h i=.03$

A significant association was found between the teachers' majors and the sources they consult about teaching except for the items of talking to colleagues and doing empirical research. The followings are the results of the chi-square tests. In all variables, $d f$ equaled 1 and $n$ equaled 142 .

Talking to colleagues: $x^{2}=2.64, p=.10, p h i=.15$

Doing empirical research: $x^{2}=3.18, p=.07, p h i=-.17$

Attending conferences or workshops: $x^{2}=4.18, p=.04, p h i=-.18$

Reading journal articles: $x^{2}=44.56, p=.00, p h i=-.57$

Reading books: $x^{2}=12.71, p=.00, p h i=-.31$

Moreover, the teachers had been given the name of 14 well-known relevant journals indexed in Thomson Reuters (ISI) to indicate which ones they read or consult for information on SLA issues. $72.5 \%$ of the teachers (31 out of 63 (49.2\%) of the TEFL majors and 72 out of $79(91.1 \%)$ of the Non-TEFL ones) stated they read none of them.

\subsection{The Frequency of Reading Research Articles}

$38.1 \%$ of the TEFL majors always or often, $44.4 \%$ of them sometimes, but $17.5 \%$ rarely read research articles. Among the Non-TEFL ones, $12.6 \%$ always or often, $43 \%$ sometimes, yet $44.3 \%$ rarely or never do it. The teachers, who stated 
they rarely or never read research articles, were asked to mention their reasons.

Table 10. Reasons for not reading SLA research

\begin{tabular}{lcccccccccc}
\hline & \multicolumn{2}{c}{ No time } & \multicolumn{2}{c}{ Difficult } & \multicolumn{2}{c}{ No interest } & \multicolumn{2}{c}{ No access } & \multicolumn{2}{c}{ Not useful } \\
\hline & Freq. & $\%$ & Freq. & $\%$ & Freq. & $\%$ & Freq. & $\%$ & Freq. & $\%$ \\
\hline TEFL & 7 & 70 & 0 & 0 & 2 & 18.2 & 3 & 30 & 0 & 0 \\
\hline Non-TEFL & 16 & 45.7 & 2 & 5.7 & 12 & 34.3 & 8 & 22.9 & 12 & 34.3 \\
\hline
\end{tabular}

The chi-square tests indicated no significant association between their reasons for not reading SLA research frequently. Whenever any cells expected count less than 5, the Fisher Exact Test was reported (Pallant 2013):

$>$ No time: $(\mathrm{n}=45), x^{2}=.99, p=.31, p h i=-.20$

$>$ Difficult to be understood: because 2 cells (50.0\%) expected count less than 5 . The minimum expected count is .48. $(\mathrm{n}=46), x^{2}=1, p=1, p h i=.12$

$>$ No easy access: because 1 cell $(25.0 \%)$ expected count less than 5, the minimum expected count is 2.44 . $(\mathrm{n}=45), x^{2}=.68, p=.96, p h i=-.06$

$>$ No interest: because 1 cell $(25.0 \%)$ expected count less than 5 . The minimum expected count is 3.35 . ( $\mathrm{n}=46)$, $x^{2}=.46, p=.52, p h i=.14$

$>$ Not useful: because 1 cell $(25.0 \%)$ expected count less than 5 . The minimum expected count is 2.87 . There is a significant association between the teachers' majors and their ideas regarding the reason that the materials are not useful. $(\mathrm{n}=46), x^{2}=.04, p=.06$. The effect size of the relationship is $p h i=.33$, meaning the effect of the major has a medium-to-large effect size on this reason.

4.5 Difference between the two Groups of Teachers Considering the Frequency of their Reading Research Articles

Table 11. Normality for the frequency of reading research articles

\begin{tabular}{lcccccc}
\hline & \multicolumn{3}{c}{ Skewness } & \multicolumn{3}{c}{ Kurtosis } \\
\cline { 2 - 7 } & Statistic & Std. Error & Normality & Statistic & Std. Error & Normality \\
\hline TEFL & .021 & .302 & .06 & -.585 & .595 & -.98 \\
Non- & -.308 & .271 & -1.13 & .311 & .535 & .58 \\
TEFL & & & & & & \\
\hline
\end{tabular}

As Table 11 reveals, the normality scores were well within \pm 1.96 limits, suggesting that the departure from normality was not too extreme (Field, 2013). Thus, an independent t-test was run to compare the mean scores of the TEFL and Non-TEFL groups in order to understand whether there was a difference between the two groups of teachers' frequency of reading research articles.

Table 12. Descriptive statistics about the frequency of reading research articles

\begin{tabular}{lcccc}
\hline Group & $\mathrm{N}$ & Mean & SD & SEM \\
\hline TEFL & 63 & 2.76 & .777 & .098 \\
Non-TEFL & 79 & 3.37 & .865 & .097 \\
\hline
\end{tabular}

Table 13: Independent t-test for the frequency of reading research articles

\begin{tabular}{|c|c|c|c|c|c|c|c|c|c|}
\hline & \multicolumn{2}{|c|}{$\begin{array}{c}\text { Levene's Test } \\
\text { for Equality of } \\
\text { Variances } \\
\end{array}$} & \multicolumn{7}{|c|}{ t-test for Equality of Means } \\
\hline & \multirow[t]{2}{*}{$\mathrm{F}$} & \multirow[t]{2}{*}{ Sig. } & \multirow[t]{2}{*}{$\mathrm{t}$} & \multirow[t]{2}{*}{$\mathrm{df}$} & \multirow[t]{2}{*}{$\begin{array}{l}\text { Sig. (2- } \\
\text { tailed) }\end{array}$} & \multirow[t]{2}{*}{ Mean Difference } & \multirow[t]{2}{*}{$\begin{array}{l}\text { Std. Error } \\
\text { Difference }\end{array}$} & \multicolumn{2}{|c|}{$\begin{array}{c}95 \% \text { Confidence } \\
\text { Interval } \\
\end{array}$} \\
\hline & & & & & & & & Lower & Upper \\
\hline $\begin{array}{l}\text { Equal variances } \\
\text { assumed }\end{array}$ & .78 & .37 & -4.33 & 140 & .000 & -.60 & .14 & -.881 & -.329 \\
\hline $\begin{array}{l}\text { Equal variances } \\
\text { not assumed }\end{array}$ & & & -4.38 & 137.98 & .000 & -.60 & .13 & -.878 & -.332 \\
\hline
\end{tabular}

The assumption of homogeneity of variances was met (Levene's $\mathrm{F}=.78, p=.78>.05$ ). That is why the first row of Table 
13, "Equal variances assumed" is reported (Pallant, 2013). Based on the results displayed in Tables 12 and 13, the difference between the two groups of teachers about the frequency of reading research articles was significant $(\mathrm{t}(140)=-$ $4.33, p<.05)$; the $\mathrm{p}$-value for this $\mathrm{t}$ was $.00(\mathrm{Sig}(2$-tailed $)=.00<.05)$; it represented a very large-sized effect $(\mathrm{r}=.34)$.

4.6 Conducting Research on SLA, Support for Research at Institutions

$24.2 \%$ of the TEFL majors and $73.1 \%$ of the Non-TEFL ones hadn't carried out any SLA research. They were asked to state their reasons.

Table 14. Reasons for not conducting SLA research

\begin{tabular}{lcccccccccc}
\hline & \multicolumn{2}{c}{ No Time } & \multicolumn{2}{c}{ No ability } & \multicolumn{2}{c}{ No interest } & \multicolumn{2}{c}{ Not useful } & \multicolumn{2}{c}{ No need } \\
\hline & Freq. & $\%$ & Freq. & $\%$ & Freq. & $\%$ & Freq. & $\%$ & Freq. & $\%$ \\
\hline TEFL & 8 & 53.3 & 5 & 33.3 & 2 & 13.3 & 0 & 0 & 0 & 0 \\
Non-TEFL & 30 & 54.5 & 19 & 34.5 & 22 & 40 & 6 & 10.9 & 5 & 9.1 \\
\hline
\end{tabular}

The following information includes the results of the chi-square tests revealing no significant association between the teachers' majors and their reasons for not conducting research. In all variables, $d f$ equaled 1 and $n$ equaled 70 .

$>$ No time: $x^{2}=.00, p=1, p h i=.01$

$>$ No ability: $x^{2}=.00, p=1, p h i=.01$

$>$ No interest: $x 2=2.63, p=.10, p h i=.23$

$>$ No need: because 2 cells $(50 \%)$ expected count less than 5 and the minimum expected count was 1.07 , so the Fisher's Exact Test was reported. $x^{2}=.57, p=.51, p h i=.14$

$>$ Not useful: because 2 cells $(50 \%)$ expected count less than 5 and the minimum expected count was 1.29 . $x^{2}=.32, p=.41, p h i=.16$

The teachers were asked whether they received any support to do research into SLA at their institute. $79.4 \%$ of the TEFL majors and $90.8 \%$ of the Non-TEFL ones (Total: $85.6 \%$ ) indicated there was no such support at the institutes they taught.

\subsection{Relevance and Usefulness of SLA Research for Classroom Teaching}

The teachers were given the following statements. They mentioned to what extent they agree on each of them.

a) Knowing about SLA research improves second language teaching practice.

In TEFL group, $88.9 \%$, and in the Non-TEFL one, $51.9 \%$ agreed or strongly agreed.

Table 15. Normality of item (a)

\begin{tabular}{lcccccc}
\hline & \multicolumn{3}{c}{ Skewness } & \multicolumn{3}{c}{ Kurtosis } \\
\cline { 2 - 7 } & Statistic & Std. Error & Normality & Statistic & Std. Error & Normality \\
\hline TEFL & 2.281 & .302 & $\underline{7.55}$ & 5.963 & .595 & $\underline{10.02}$ \\
Non-TEFL & .636 & .271 & $\underline{2.34}$ & .611 & .535 & 1.14 \\
\hline
\end{tabular}

As Table 15 indicates, the data did not enjoy normal distribution, i.e., the outcomes were not within the ranges of $+/-$ 1.96 (Field, 2013). As a result, Mann-Whitney U Test was run to find out whether there was any significant difference between the ideas of teachers. The test revealed a significant difference between the opinions of the two groups. (TEFL $(n=63)$; Non-TEFL $(n=79))$. Nevertheless, the $M d$ in both groups with was the item "agree". $U=1415, z=-4.65$, $p=.00, \mathrm{r}=-.39$.

b) SLA research provides teachers with practical suggestions for improving second language instruction.

In TEFL group, $82.5 \%$, and in Non-TEFL one, $50 \%$ agreed or strongly agreed.

Table 16. Normality of item (b)

\begin{tabular}{lcccccc}
\hline & \multicolumn{3}{c}{ Skewness } & \multicolumn{3}{c}{ Kurtosis } \\
\cline { 2 - 7 } & Statistic & Std. Error & Normality & Statistic & Std. Error & Normality \\
\hline TEFL & 2.142 & .302 & $\underline{7.09}$ & 7.114 & .595 & $\underline{11.95}$ \\
Non-TEFL & .425 & .276 & 1.53 & -.504 & .545 & -0.92 \\
\hline
\end{tabular}

Because the data in the TEFL group did not enjoy the normality assumption, the Mann-Whitney U Test was run to 
probe the difference between groups of teachers'ideas. The test indicated a significant difference between the opinions of both groups. $(\operatorname{TEFL}(\mathrm{n}=63)(M d=$ agree $))$; $($ Non-TEFL $(\mathrm{n}=76)(M d=$ near "somewhat agree") $), \mathrm{U}=1633, \mathrm{z}=-3.36, p=.00$, $\mathrm{r}=.28$.

c) SLA research is not relevant to language teaching.

In TEFL, $87.3 \%$, but in Non-TEFL one, $62.1 \%$ disagreed or strongly disagreed. In TEFL group, $3.2 \%$ strongly agreed and $4.8 \%$ somewhat agreed. In Non-TEFL one, $2.5 \%$ agreed and $11.4 \%$ somewhat agreed.

Table 17. Normality of item (c)

\begin{tabular}{lcccccc}
\hline & \multicolumn{3}{c}{ Skewness } & \multicolumn{3}{c}{ Kurtosis } \\
\cline { 2 - 7 } & Statistic & Std. Error & Normality & Statistic & Std. Error & Normality \\
\hline TEFL & -2.315 & .302 & $\underline{-7.66}$ & 7.354 & .595 & $\underline{12.35}$ \\
Non-TEFL & -.541 & .271 & $\underline{-1.99}$ & -.304 & .535 & -.56 \\
\hline
\end{tabular}

As Table 17 indicates, the data did not enjoy normal distribution. Consequently, the Mann-Whitney U Test was run to investigate the difference between the two groups of ideas. The test showed a significant difference between the opinions of both groups. However, the $M d$ in both groups was the item "disagree". (TEFL(n=63); Non-TEFL(n=79)), $\mathrm{U}=1756, \mathrm{z}=-3.18, p=.00, \mathrm{r}=.26$.

d) The knowledge I gain from teaching experience is more relevant to my teaching than the knowledge I gain from SLA research.

In TEFL group, 9.5\% agreed and 20.6\% somewhat agreed, but in the Non-TEFL one, the statistics showed $33.3 \%$ agreed or strongly agreed and $35.9 \%$ somewhat agreed.

Table 18. Normality of item (d)

\begin{tabular}{lcccccc}
\hline & \multicolumn{3}{c}{ Skewness } & \multicolumn{3}{c}{ Kurtosis } \\
\cline { 2 - 7 } & Statistic & Std. Error & Normality & Statistic & Std. Error & Normality \\
\hline TEFL & -.638 & .302 & $\underline{-2.11}$ & -.800 & .595 & -1.34 \\
Non-TEFL & -.300 & .272 & -1.10 & -.764 & .538 & -1.42 \\
\hline
\end{tabular}

As Table 18 shows, in TEFL group, the outcome of ratio of skewness over its standard errors was not within the ranges of $+/-1.96$, so the data did not enjoy normal distribution. The Mann-Whitney U Test revealed a significant difference between the opinions of both groups. The $M d$ in TEFL group (n=63) was the item "somewhat disagree", whereas it was "somewhat agree" in Non-TEFL one $(\mathrm{n}=78), \mathrm{U}=1487, \mathrm{z}=-4.15, p=.00, \mathrm{r}=.34$.

\subsection{Teacher-researcher Relationship}

The teachers were given the following statements and they were asked to mention to what extent they agree.

a) Researchers should be university professors or academics, but not teachers.

In TEFL group, $98.4 \%$ disagreed or strongly disagreed and nobody in this group agreed on this idea, but in Non-TEFL group, $75.9 \%$ disagreed or strongly disagreed, yet $10.1 \%$ in this group agreed or strongly agreed and $6.3 \%$ somewhat agreed.

Table 19. Normality of item (a)

\begin{tabular}{lcccccc}
\hline & \multicolumn{3}{c}{ Skewness } & \multicolumn{3}{c}{ Kurtosis } \\
\cline { 2 - 7 } & Statistic & Std. Error & Normality & Statistic & Std. Error & Normality \\
\hline TEFL & -.167 & .302 & -.55 & -1.281 & .595 & $\underline{-2.15}$ \\
Non-TEFL & -1.323 & .271 & $\underline{-4.88}$ & .929 & .535 & 1.73 \\
\hline
\end{tabular}

As Table 19 indicates, the data did not enjoy normal distribution. Therefore, the Mann-Whitney U Test was run. It proved there was a significant difference between the opinions of both groups of teachers. The $M d$ in both groups was the item "disagree". (TEFL( $\mathrm{n}=63)$, Non-TEFL( $\mathrm{n}=79)$ ), $\mathrm{U}=1984, \mathrm{z}=-2.25, p=.02, \mathrm{r}=.18$.

b) Researchers should carry out research and teachers should teach.

In TEFL group, $82.6 \%$, and in Non-TEFL one, $68.4 \%$ disagreed or strongly disagreed. 


\begin{tabular}{lcccccc}
\hline & \multicolumn{3}{c}{ Skewness } & \multicolumn{3}{c}{ Kurtosis } \\
\cline { 2 - 7 } & Statistic & Std. Error & Normality & Statistic & Std. Error & Normality \\
\hline TEFL & -1.349 & .302 & $\underline{-4.46}$ & 2.253 & .595 & $\underline{3.78}$ \\
Non-TEFL & -.718 & .271 & $\underline{-2.64}$ & -.383 & .535 & -.71 \\
\hline
\end{tabular}

Table 20 indicates that the data did not enjoy normal distribution. The Mann-Whitney U Test showed a significant difference between the opinions of both groups. The Md in both groups was the item "disagree", however. (TEFL(n=63), Non-TEFL(n=79)), $\mathrm{U}=2017, \mathrm{z}=-2.09, p=.03, \mathrm{r}=-.17$.

c) Teachers and researchers should work together.

In TEFL group, $87.1 \%$ and in Non-TEFL one, $68.4 \%$ agreed or strongly agreed.

Table 21. Normality of item (c)

\begin{tabular}{lcccccc}
\hline & \multicolumn{3}{c}{ Skewness } & \multicolumn{3}{c}{ Kurtosis } \\
\cline { 2 - 7 } & Statistic & Std. Error & Normality & Statistic & Std. Error & Normality \\
\hline TEFL & 2.072 & .304 & $\underline{6.81}$ & 7.060 & .599 & $\underline{11.78}$ \\
Non-TEFL & .397 & .271 & 1.46 & -.531 & .535 & -.99 \\
\hline
\end{tabular}

As Table 21 shows, the data did not enjoy normal distribution. The Mann-Whitney U Test indicated a significant difference between the opinions of both groups, but the $M d$ in both groups, was the item "agree". (TEFL(n=62), (Non$\operatorname{TEFL}(\mathrm{n}=79)), \mathrm{U}=1751, \mathrm{z}=-3.09, p=.00, \mathrm{r}=-.26$.

d) Teachers should consult researchers for advice on teaching and learning issues.

In TEFL group, $75.8 \%$ and in Non-TEFL one, $74.7 \%$ agreed or strongly agreed.

Table 22. Normality of item (d)

\begin{tabular}{lcccccc}
\hline & \multicolumn{3}{c}{ Skewness } & & \multicolumn{3}{c}{ Kurtosis } \\
\cline { 2 - 7 } & Statistic & Std. Error & Normality & Statistic & Std. Error & Normality \\
\hline TEFL & .830 & .304 & $\underline{\mathbf{2 . 7 3}}$ & 1.521 & .599 & $\underline{\mathbf{2 . 5 3}}$ \\
Non-TEFL & 1.543 & .271 & $\underline{\mathbf{5 . 6 9}}$ & 3.938 & .535 & $\underline{\mathbf{7 . 3 6}}$ \\
\hline
\end{tabular}

Table 22 indicates that the data did not enjoy normal distribution. The Mann-Whitney U Test revealed no significant difference between the opinions of both groups. The $M d$ in both groups was the item "agree". (TEFL(n=62) (Non$\operatorname{TEFL}(\mathrm{n}=79), \mathrm{U}=2426, \mathrm{z}=-.10, \mathrm{p}=.91, \mathrm{r}=-.008$.

e) Researchers should consult teachers for advice on issues they want to research.

In TEFL group, $76.2 \%$ and in Non-TEFL one, $74.7 \%$ agreed or strongly agreed.

Table 23. Normality of item (e)

\begin{tabular}{lcccccc}
\hline & \multicolumn{3}{c}{ Skewness } & & \multicolumn{3}{c}{ Kurtosis } \\
\cline { 2 - 7 } & Statistic & Std. Error & Normality & Statistic & Std. Error & Normality \\
\hline TEFL & 1.138 & .302 & $\underline{3.76}$ & 2.288 & .595 & $\underline{3.84}$ \\
Non-TEFL & .665 & .271 & $\underline{2.45}$ & 2.025 & .535 & $\underline{3.78}$ \\
\hline
\end{tabular}

As the data did not enjoy normal distribution, the Mann-Whitney U Test was run. It showed no significant difference between the opinions of both groups, yet the $M d$ in both groups was the item "agree". (TEFL(n=63)), (Non$\operatorname{TEFL}(\mathrm{n}=79)), \mathrm{U}=2366.500, \mathrm{z}=-.55, p=.57, \mathrm{r}=-.04$.

\section{Discussion and Conclusion}

This study explored the Iranian EFL teachers' familiarity, involvement with, accessibility to, and their judgments about the usefulness of SLA research. The sources the teachers consult about teaching and SLA research were investigated. Furthermore, the existence of any significant associations between the teachers' majors and the raised issues or any significant differences between the two participating groups of teachers' perspectives on the mentioned subjects were also investigated. 
Significant differences were found between the ideas of two groups of teachers about the issues of relevance and usefulness of SLA research for classroom teaching, but considering the previous Iranian researchers' findings, what was revealed in this part of the study regarding the issue of practicality of SLA findings is strange and needs more investigation; only $3.2 \%$ of the TEFL-major teachers and $18.4 \%$ of the non-TEFL-major ones disagreed that SLA research provides teachers with practical suggestions for improving second language instruction. Nevertheless, in another section of this study, 34.3\% teachers declared that reading research articles is not useful; as it was mentioned earlier, this finding needs more investigation. This finding does not support what Nassaji (2012), Mehrani and Behzadnia's (2013), Mehrani (2015), as well as Talebinejad and Moattarian's (2015) found, either; the EFL Iranian teachers in the previous studies mentioned applying SLA research in language teaching in classrooms is sometimes impractical.

A significant association was also found between the teachers' majors and their access to SLA materials. Surprisingly, $78.5 \%$ of the teachers in the non-TEFL group stated they could access readings on SLA research, but the percentage among the TEFL majors was $55.6 \%$. The most common sources teachers in both groups indicated as what they consult about both research and teaching were books, online journals, the Internet, and colleagues. Doing empirical research was the least popular source among them (19\% in TEFL group and $7.6 \%$ in Non-TEFL one). On the other hand, the participating teachers were given the names of 14 well-known journals and asked whether they consult them. $49.2 \%$ of the TEFL-major teachers and $91.1 \%$ of the non-TEFL-major ones stated they read none of them. These findings support what Mehrani and Behzadnejad (2013) found. In addition, a significant difference was revealed between the two groups of teachers regarding the frequency of reading research articles. About half of the non-TEFL-major teachers stated they rarely or never read research articles. Such findings were revealed by Crookes and Arakaki (1999), which was considered a problematic situation and was attributed to the teachers' working conditions in their study.

Regarding the reasons teachers had for not reading the research articles, a lack of time was also the most important and frequent reason. Not being interested in reading such materials and not being useful were the other frequent reasons among the Iranian non-TEFL-major teachers (34.3\% for each reason). Such findings had already been found by Borg (2007, 2009), Nassaji (2012), Mehrani and Behzadnia (2013), and Talebinejad and Moattarian (2015). The finding about the lack of time supports the concerns that have been expressed in the field of SLA (Crookes, 1997). As Nassaji (2012) assured, when teachers cannot spend enough time reading or conducting research, they do not benefit directly from research findings even if they agree it is useful for teaching. To improve the situation, Nassaji (2012) remarked language teaching institutions had better consider ways to provide teachers with necessary time and resources to improve their teaching.

In addition, very few non-TEFL-major teachers (5.7\%) and no one in TEFL group pointed to the item of the difficulty of the materials as a reason for not reading the research articles. Not only is this finding contradictory with what Brown (1991), Crookes (1997), Ellis (1997), Nassaji (2012), Mehrani and Behzadnia (2013), Mehrani (2014), as well as Talebinejad and Moattarian (2015) found, but it is also strange because about a third of the non-TEFL-major teachers stated they had not taken any courses on research methods or SLA (35.4\% and 39\%, respectively). As the SLA materials include research or pedagogical terminology, the teachers may not be competent enough to understand the researchers' discourse and what exactly the terms mean unless they pass the relevant courses. Thus, this finding cannot be reliable and more investigation is needed.

Moreover, significant associations were found between the teachers' majors and their familiarity with SLA research. About a third of the non-TEFL-major teachers had taken courses on neither SLA nor research methods. Of those nonTEFL-major teachers who had already taken courses on research methods, $35.3 \%$ indicated that they were somewhat useful or not useful at all. This piece of information can be a reason why $73.1 \%$ of them had not conducted research because as Ellis (2010) assured, "a familiarity with SLA will help teachers identify and shape problems about learners and learning as well as inform them about the kinds of instruments and procedures they will need to investigate them." (p. 194). Although the situation was better in TEFL group, $41.3 \%$ of them did not find the courses on research methods useful, either; thus, about a third of the TEFL majors had never done any SLA research. In fact, no significant difference was found between the two groups of teachers' ideas about the usefulness of courses on research methods. Moreover, $33.3 \%$ of the teachers certified in TEFL and $34.5 \%$ of the non-TEFL-major teachers mentioned the lack of ability as their reasons for not conducting research which could be a reason for the inefficacy of the courses on research methods in Iran. In literature, Gass (1995, as cited in Nassaji, 2012) suggested teacher educators incorporate SLA research-based courses in teacher education programs in order to assist teachers in being familiar with research formats, the language, and the discourse used by researchers to report research results. Brown (1991) even advised the teacher educators to increase the teachers' knowledge of statistics to understand the SLA studies thoroughly. Nonetheless, considering the context of Iran, the applied teaching approaches are usually theoretical rather than practical at the university level (Avanaki \& Sadeghi, 2013) and in teacher education programs in general (Farhady et al, 2010; Jadidi \& Bagheri, 2014; Karimvand, et al, 2014; Nezakat-Alhossaini \& Ketabi, 2010; Sarlak \& Vafaeimehr, 2014) The participating TEFL students at MA level in Khoshsaligheh, Jamali, and Saeedian's (2014) as well as Moiinvaziri and Razmjoo's (2016) studies were also dissatisfied with the current English language education planning and curriculum development offered in the universities, textbooks, and the university instructors' teaching methods. The participating teachers in Mehrani's (2014) study also complained about the theoretical discussions in teacher education courses and claimed that "when they take a course of research during their teacher education programs, they are taught some theoretical discussions, and are simply expected to memorize the content of a book" (p. 29). All the participants in Mehrani's study believed that the authorities should note this problem and make necessary modifications to improve the TEFL in Iranian educational 
system.

In addition to the lack of ability, a lack of time and a lack of interest were the other frequent reasons for not doing research. These reasons had been mentioned by the Iranian EFL teachers in Mehrani and Behzadnia's (2013) study as well. The teachers' statement of the lack of interest in doing research "may imply a lack of awareness of the professional and pedagogical benefits which research engagement might lead to" (Borg, 2007, p. 743). Richards and Farrell (2005, p. 173) stated that "teachers who have carried out action research often report significant changes to their understanding of teaching." Advocates of action research suggest that teachers add a research dimension to their teaching practice in order to better understand and improve it (Richards \& Farrell, 2005). Action research can also assist teachers in promoting their professional development (Crookes, 1993; Crookes \& Chandler, 2001; Norton, 2009; Nunan, 1997; Somekh, 2006).

Borg (2007) also stated the literature highlighted that when institutions provide an environment conducive to research engagement, teachers read and do research more frequently. As Borg argued, "sustained and productive research engagement is not feasible unless the time it requires is acknowledged and built into institutional systems.” (p. 744). In addition, Nunan (2005) had already stated, to do research, teachers would need the support of a trained supervisor, but as he expressed, unfortunately, in most contexts, [like Iran], these expectations are currently less-than-realistic wishes; a very high percentage of the Iranian participating teachers in this study (90.8\%) stated there is no support to do research in the institutes they teach. The statistic for this issue in the EFL context of Turkey was 48\% in Nassaji's (2012) study. Dörnyei (2007) provided his own experience which can be seen in the context of Iran. Dörnyei stated that many teachers

could be motivated to engage in some meaningful exploration activity, even spending some of their free time on it, if there was some institutional incentive for it in the form of, for example, official recognition, financial reward, or release time. This, however, hardly ever happens, and even in contexts where teachers are provided with in-service training, this tends to involve lectures or workshops rather than some form of action research. (p. 192)

Burns (2012) reported the positive impacts of an instructional program preparing the teachers for doing research. The program was sponsored by the institutions where the teachers worked. The participants emphasized that the program had positive personal and professional impact on them. Burns $(2012$, p. 4) stated the program led to the following outcomes:

- greater consciousness-raising and curiosity about classroom practice

- deeper ability and confidence to face and resolve classroom problems

- personal satisfaction in carrying out and learning more about research

- a greater sense of credibility bestowed by doing research as a teacher

- a 'ripple-effect' from their research on other colleagues at their teaching centers.

Moreover, the institutions' academic managers in Burns's study believed that

there were benefits not only for the individual teachers whose participation they had sponsored, but also positive 'ripple effects' among other teachers organizationally. These included a strengthening of teachers' concepts of the links between practice and professional development, greater interest in and engagement with teacher-initiated research, and an increased sense of professionalism that related to growing awareness of a wider world within and outside the institution. The managers also reflected on the personal growth, increased confidence and motivation they had observed in the teacher researchers. (p. 5)

As Richards and Farrell (2005) said, most successful educational institutions regard the training and development of their teachers as a matter of high priority because such improvement will lead to achieving better learning outcomes as well as attracting more students. Consequently, not only the Iranian teachers but also the institutions' managers in Iran had better be aware of the benefits of such training and support.

Concerning the item of teacher-researcher relationship, many EFL teachers in this study seem to be willing to do action research. This finding supports what Mehrani and Behzadnia (2013), Mehrani (2014), as well as Talebinejad and Moattarian (2015) found. Doing action research is known as a way to bridge the gap between researchers and teachers (Behzadi \& Sayadian 2015). Moreover, encouraging teachers to do action research can make them familiar with research skills and improve their knowledge of doing research (Crookes \& Chandler, 2001). A collaborative approach in which research is done by both researchers and teachers has been highly recommended (e.g., Crookes 1993, 1997; Roberts 1993; Ellis 1997; Lightbown 2000) to improve the relationship between research and pedagogy. Concerning the context of Iran, it is necessary to improve the teacher-researcher collaboration.

Furthermore, as Nassaji (2012, p. 342) assured, the researchers "will interpret the findings mainly from their own viewpoint". Labaree (2003) also said the problems of teaching practice cannot be solved if there is not a deep comprehensive understanding of the context of teaching. Widdowson (1990) also pointed out that teachers should ultimately decide on the relevance of the SLA research to their teaching. To improve the situation, teachers and researchers can have active dialogues with each other about the issue of their mutual interest (Crookes, 1998). In addition, they can do and publish research projects collaboratively inside the classroom (Lightbown, 2000).

Nonetheless, teacher-researcher collaboration seems somewhat idealistic or lofty in some unfavorable language teaching contexts in some countries (Borg, 2010). Borg (2010) listed some barriers to teacher research. The list includes: 
"non-collaborative school culture, limitations in teachers' awareness, beliefs, skills and knowledge, limited resources, demotivators, economic matters, leadership attributes, and political issues" (p. 409). Some of the mentioned barriers are seen in the context of language teaching in Iran and were mentioned in Mehrani and Behzadnia (2013).

In light of the discussed issues as well as the earlier findings in literature which were reported in the Introduction, the essential initial corrective step to be taken in Iran seems to be changing the format of the EFL teacher education and supervision" which needs to be done especially by ELT policy makers and experts. Consequently, a culture which Hargreaves (1992, as cited in Johnston, 2009) had called, a culture of collaboration will be created.

The problem with the current Iranian EFL TTCs was one of the complaints of the EFL teachers in Talebinejad and Moattarian's (2015) research. There is no opportunity for creativity, critical reflection, active participation and collaborative reflection because in Iran, EFL teacher education has a mainly positivistic and transmission-oriented approach in which the prospective teachers are mainly passive recipients of deposits of pre-selected knowledge transferred by their trainers. (Farhady, et al, 2010; Jadidi \& Bagheri 2014; Karimvand, et al, 2014). Therefore, in addition to the traditional forms of teacher education, more innovative educational practices, such as awareness-raising activities based on published research and action research projects can also have great impacts at least on the teachers' beliefs about language learning (Angelova, 2005, as cited in Ellis, 2010; Erlam, 2008; McDonough, 2006); Besides, the length of the TTCs also needs to be long enough to cover all ELT issues, so the teachers' professional knowledge can enhance and the relationship between SLA research and ELT in Iran can promote (Karimvand et al, 2014).

Moreover, after passing the TTCs and while working as a teacher, EFL teachers in Iran cannot move out of their submissive position and take an innovatory role due to classroom observations, supervisors' and managers' criticism, which do not allow teachers to deviate from the techniques taught in TTCs. The supervision system in Iran is still the traditional directive one in Gebhard's term (1984) or what Freeman (1982) had called, the supervisory option in which the supervisor is an expert who provides teachers with prescriptive advice; the supervisor is the power who determines how teachers should teach Furthermore, the problem Brown (2001) mentioned about language teacher mentoring is still seen in Iran's language teacher supervision system; sometimes clashes occur between a supervisor, who teaches English in traditional ways, and the teacher whose approach is more communicative. In these situations, it's the teacher who has to respect and accept the authority. If teachers rebelled against or rejected the supervisor's ideas, they might suffer the unpleasant consequences. This claim was proved in Moradi, et al's (2014) study. Talebinejad and Moattarian (2015, p. 7) also stated that teachers have to "apply the method presented in TTCs step by step. Hence, no deviation from the rules is allowed, and consequently, there is no room for applying the results of the research in their classes". Thus, Iran's EFL teachers condition is not in accord with what Kumaravadivelu (2006), called as suitable for the post method condition which clearly signifies teacher autonomy. As Ellis (2010) stated,

Teachers need opportunities to become researchers in their own classroom as well as consumers of SLA research. This can be achieved in a variety of ways - through collaborative research with an SLA researcher or through action research and exploratory practice. (p. 196)

\section{Acknowledgements}

We would like to thank Professor Hossein Nassaji who permitted the authors to use his questionnaire to do this study. His permission was granted on March 2nd, 2013 via email. Also, special thanks go to the teachers who participated in this study.

\section{References}

Akbari, R. (2008). Postmethod discourse and practice. TESOL Quarterly, 42.2, $641 \quad-\quad 652$. http://dx.doi.org/10.1002/j.1545-7249.2008.tb00152.x

Akbari, R. \& Yazdanmehr, E. (2011). EFL teachers' recruitment and dynamic assessment in private language institutes of Iran. Journal of English Language Teaching and Learning, 8, 29-51. Retrieved from elt.tabrizu.ac.ir/pdf_612_ac98fb22e3ffc2cae5eee1b35df6d22e.html

Allwright, D. (2005). From teaching points to learning opportunities and beyond. TESOL Quarterly, 39(1), 9-31. http://dx.doi.org/10.2307/3588450

Atai, M. R. \& Mazlum, F. (2013). English language teaching curriculum in Iran: planning and practice. The Curriculum Journal, 24(3), 389-411. http://dx.doi.org/10.1080/09585176.2012.744327

Avanaki, H. J. \& Sadeghi, B (2013). English language teaching (ELT) in Iranian universities in brief. Theory and Practice in Language Studies, 3(12), 2296-2302. Retrieved from www.academypublication.com/issues/past/tpls/vol03/12/21.pdf

Bartels, N. (2003). How teachers and researchers read academic articles. Teaching and Teacher Education, 19(7), 73753. http://dx.doi.org/10.1016/j.tate.2003.06.001

Beh-Afarin, S. R. (2003). ELT teacher education evaluation: Assessment of needs, pedagogical constraints, and objective setting in EFL teacher education programs (TEPS). Unpublished $\mathrm{PhD}$ dissertation. Tehran, Islamic Azad University: Science and Research Campus 
Behzadi, A. \& Sayadian, S. (2015). The relevance of SLA research to language teaching from teachers' perspective. International Journal of Educational Investigations, 2(1), 19-24. Retrieved from http://www.ijeionline.com/attachments/article/35/IJEIonline_Vol.2_No.1_2015-1-03.pdf

Block, D. (2000). Revisiting the gap between SLA researchers and language teachers. Links \& Letters, 7, $129-43$. Retrieved from www.raco.cat/index.php/LinksLetters/article/download/22721/22555

Borg, S. (2007). Research engagement in English language teaching. Teaching and Teacher Education 23, 731-747. http://dx.doi.org/10.1016/j.tate.2006.03.012

Borg, S. (2009). English language teachers' conceptions of research. Applied Linguistics, 30(3), 355-88. http://dx.doi.org/10.1093/applin/amp007

Borg, S. (2010). Language teacher research engagement. Language Teaching, 43(4), 391-429. http://dx.doi.org/ $10.1017 / \mathrm{S} 0261444810000170$

Brown, J. D. (1991). Statistics as a foreign language; Part 1: What to look for in reading statistical language studies. TESOL Quarterly, 25(4), 569-86. http://dx.doi.org/10.2307/3587077

Brown, K. (2001). Mentoring and the retention of newly qualified language teachers. Cambridge Journal of Education, 31(1), 69-88. http://dx.doi.org/10.1080/03057640124093

Burns, A. (2012, May). Teacher research in a national programme: Impact and implications. Cambridge ESOL: Research Notes, 48, 3-7. Retrieved from www.cambridgeenglish.org/images/23165-research-notes-48.pd

Crookes, G. (1993). Action research for second language teachers: Going beyond teacher research. Applied Linguistics, 14(2), 130-44. http://dx.doi.org/10.1093/applin/14.2.130

Crookes, G. (1997). SLA and language pedagogy: A socioeducational perspective. Studies in Second Language Acquisition, 20, 93-116. Retrieved from http://sls.hawaii.edu/Gblog/wp-content/uploads/2011/08/Crookes-SSLA2011997.pdf

Crookes, G. (1998). On the relationship between second and foreign language teachers and research. TESOL Journal, 7 , 6-11. Retrieved from http:// sls.hawaii.edu/Gblog/wp-content/uploads/.../Crookes-TJ73-1998.pdf

Crookes, G. \& Arakaki, L. (1999). Teaching idea sources and work conditions in an ESL program. TESOL Journal, 8, 15-19. http://dx.doi.org/10.1002/j.1949-3533.1999.tb00151.x

Crookes, G. \& Chandler, P. M. (2001). Introducing action research into the education of postsecondary foreign language teachers. Foreign Language Annals, 34, 131-40. http://dx.doi.org/10.1111/j.1944-9720.2001.tb02818.x

Dahmardeh, M. (2009). Communicative textbooks: English language textbooks in Iranian secondary school. Linguistik online, 4(09), 45-61. Retrieved from www.linguistik-online.org/40_09/dahmardeh.pdf

Davari, H. \& Aghagolzadeh, F. (2015). To teach or not to teach? Still an open question for the Iranian education system. In C. Kennedy (ed.), English language teaching in the Islamic Republic of Iran: Innovations, trends and challenges. (pp. 13 - 18). British Council.www.britishcouncil.ir/sites/.../english_language_teaching_in_iran_0.pdf

Dörnyei, Z. (2007). Research methods in applied linguistics: Quantitative, Qualitative, and Mixed Methodologies. Oxford: Oxford University Press.

Ellis, R. (1997). SLA and language pedagogy: An educational perspective. Studies in Second Language Acquisition, 20 , 69-92. http://dx.doi.org/10.1017/S0272263197001058

Ellis, R. (2010). Second language acquisition, teacher education and language pedagogy. Language teaching, 43(2), 182-201. http://dx.doi.org/ 10.1017/S0261444809990139

Erlam, R. (2008). What do you researchers know about language teaching? Bridging the gap between SLA research and language pedagogy. Innovation in Language Learning and Teaching 2(3), 253-267. http://dx.doi.org/10.1080/17501220802158958

Farhady, H., Sajadi, F. H., \& Hedayati, H. (2010). Reflections on foreign language education in Iran. TESL-EL, 13(4), 1-18. Retrieved from http://tesl-ej.org/pdf/ej52/a1.pdf

Fernandez-Balboa, J. M., \& Marshall, J. P. (1994). Dialogical pedagogy in teacher education: Toward an education for democracy. Journal of Teacher Education, 45(3), 172-182. http://dx.doi.org/10.1177/0022487194045003003

Field, A. (2013). Discovering statistics using SPSS. (4th ed.). London: Sage.

Freeman, D. (1982). Observing teachers: Three approaches to inservice training and development. TESOL Quarterly, 16(1), 21-28. http://dx.doi.org/10.2307/3586560

Gebhard, J. G. (1984). Models of supervision: Choices. TESOL Quarterly, 18(3), 501-514. http://dx.doi.org/10.2307/3586717

Jadidi, E. \& Bagheri, M. S. (2014). ELT pre-service teacher education: Major trends and shifts. International Journal of Language Learning and Applied Linguistics World (IJLLALW), 7(4), 181-190. Retrieved from www.ijllalw.org/finalversion7415.pdf

Johnston, B. (2009). Collaborative Teacher Development. In A. Burns, \& J. C. Richards (Eds): The Cambridge Guide to Second Language Teacher Education. (pp. 241-249). UK: Cambridge University Press. 
Karimi (Allvar), M. N. (2011). Variations in EFL teachers' pedagogical knowledge base as a function of their teaching license status. The Journal of Teaching Language Skills (JTLS), 3(3), 83-114. Retrieved from jtls.shirazu.ac.ir/pdf_379_6ccac0606c1d0033615189cac5dc52c2.html

Karimvand, P. N.., Hessamy, G., \& Hemmati, F. (2014). The place of postmethod pedagogy in teacher education programs in EFL language centers of Iran. Iranian Journal of Applied Linguistics (IJAL),17(2), 59-91. www.ensani.ir/storage/Files/20150706143329-9829-56.pdf

Khoshsaligheh, M., Jamali, F., \& Saeedian, A. (2014). Attitude of Iranian graduate students toward English: A case study. English Language Teaching (ELT), 1(2), 105-126. Retrieved from http://elt.journals.ikiu.ac.ir/article_573_50f3052e279c63be066c5e19cb3816bc.pdf

Klein, W. (1998). The contribution of second language acquisition research. Language Learning, 48(4), 527-49. http://dx.doi.org/10.1111/0023-8333.00057

Kumaravadivelu, B. (2006). Understanding language teaching from method to post-method. London: Lawrence Erlbum Associates.

Labaree, D. F. (2003). The peculiar problems of preparing educational researchers. Educational Researcher, 32, $13-22$. http://dx.doi.org/10.3102/0013189X032004013

Larsen-Freeman, D. (1998). On the scope of second language acquisition research: "The learner variety" perspective and beyond-A response to Klein. Language Learning, 48(4), 551-556. http://dx.doi.org/10.1111/0023-8333.00058

Lightbown, P. (2000). Anniversary article: Classroom SLA research and second language teaching. Applied Linguistics, 21(4), 431-62. https://doi.org/10.1093/applin/21.4.431

Maftoon, P., Yazdani, M. M., Gholebostan, H., \& Beh-Afarin, S. R. (2010). Privatization of English education in Iran: A feasibility study. TESL-EL, 13.4, 1-12. Retrieved from www.tesl-ej.org/wordpress/issues/volume13/ej52/ej52a8/

McDonough, K. (2006). Action research and the professional development of graduate teaching assistants. The Modern Language Journal 90(1), 33-47. http://dx.doi.org/10.1111/j.1540-4781.2006.00383.x

Mehrani, M. B. (2014). Bridging the gap between research and practice: Voice of mediators. Journal of Pan-Pacific Association of Applied Linguistics, 18(2), 21-38. Retrieved from paal.kr/download/18_2/18-2-2_Mehdi_B_Mehrani.pdf

Mehrani, M. B. (2015). English teachers' research engagement: Level of engagement and motivation. Iranian Journal of Language Teaching Research, 3(1), 83-97. Retrieved from www.urmia.ac.ir/sites/www.urmia.ac.ir/files/Article5.pdf

Mehrani, M. \& Behzadnia, A. (2013). English teachers' research engagement: Current barriers and future strategies. International Journal of Foreign Language Teaching and research, 2(4), 17-32. Retrieved from jfl.iaun.ac.ir/article_10579_33ad3515735f15677714420ea64c7ece.pdf

Moghaddas, B., \& Zakeri, J. (2012). English teacher education in Iran. E L T V o i c e s-India, 2(4), 18-32. Retrieved from https://www.academia.edu/21136191/English_Teacher_Education_in_Iran?auto=download

Mohammadi, S., Karimian, Z., \& Talebinejad, M. R. (2015). Iranian EFL teachers' attitudes towards in-service professional development programs. Journal of Applied Linguistics and Language Research, 2(3), 48-60. Retrieved from www.jallr.com/index.php/JALLR/article/viewFile/41/pdf_39

Mohsenian, M., Rezai, A., \& Abdolmanafi-Rokni, S. J. (2015). An investigation into the criteria for selecting teachers in English language institutes in Iran. Journal of Applied Linguistics and Language Research, 2(5), 215-230. Retrieved from www.jallr.com/index.php/JALLR/article/download/113/pdf113

Moiinvaziri, M. \& Razmjoo, S. A. (2016). Teachers-to-be voices: A grounded theory approach towards challenges facing Iranian EFL M.A. candidates. Journal of Research in Applied Linguistics, 7(1), 54-74. Retrieved from rals.scu.ac.ir/article_11777_7002122d166bf90b6bb4099b664fe21d.pdf

Montgomery, D. (1997). Teaching teachers for creativity. High Ability Studies, 8(1), $79-93$. http://dx.doi.org/10.1080/1359813970080107

Moradi, K., Sepehrifar, S., \& Parhizkar Khadiv, T. (2014). Exploring Iranian EFL teachers' perceptions on supervision. Procedia of International Conference on Current Trends in ELT. Social and Behavioral Sciences, 98, $1214-1223$. http://dx.doi.org/10.1016/j.sbspro.2014.03.536

Nassaji, H. (2012). The relationship between SLA research and language pedagogy: Teachers' perspectives. Language Teaching Research, 16(3), 337-365. http://dx.doi.org/10.1177/1362168812436903

Navidinia, H., Kiani, G. R., Akbari, R., \& Ghafar Samar, R. (2014). EFL teacher performance evaluation in Iranian high schools: Examining the effectiveness of the status quo and setting the groundwork for developing an alternative model. The International Journal of Humanities, 21(4), 27-53. Retrieved from eijh.modares.ac.ir/article_13102_ce997fec0cf7984d3eb5b2f52eef7924.pdf

Nezakat-Alhossaini, M., \& Ketabi, A. S. (2012).Teacher training system and EFL classes in Iran. [Procedia of Akdeniz Language Studies Conference]. Social and Behavioral Sciences, 70(3), $526 \quad-536$. http://dx.doi.org/10.1016/j.sbspro.2013.01.090

Norton, L. S. (2009). Action research in teaching and learning: A practical guide to conducting pedagogical research in universities. Abingdon, Oxon: Routledge. 
Nunan, D. (1997). Developing standards for teacher-research in TESOL. TESOL Quarterly, 31(2), 365-67. http://dx.doi.org/10.2307/3588053

Nunan, D. (2005). 'Classroom research' in E. Hinkel (ed.). Handbook of Research in Second Language Teaching and Learning. Mahwah, N.J.: Lawrence Erlbaum.

Pallant, J. (2013). SPSS survival manual: A step by step guide to data analysis using IBM SPSS. (5 ${ }^{\text {th }}$ ed.). Berkshire, England: Open University Press.

Rahmany, R., Hasani, M. T., Parhoodeh, K. (2014). EFL teachers' attitudes towards being supervised in an EFL context. Journal of Language Teaching and Research, 5(2), 348-359. http://dx.doi.org/10.4304/jltr.5.2.348-359

Razi, N., \& Kargar, A. A. (2014). Evaluation of in-service foreign language teacher education program in Iran. International Journal of Language Learning and Applied Linguistics World, 5(1), 221-236. Retrieved from www.ijllalw.org/finalversion5118.pdf

Richards, J. C., \& Farrell, T. S. C. (2005). Professional development for language teachers: Strategies for teacher learning. Cambridge, UK: Cambridge University Press.

Roberts, J. R. (1993). Evaluating the impact of teacher research. System, 21(1), 1-19. http://dx.doi.org/10.1016/0346251X(93)90003-Y

Samar, R. G., Mehrani, M. B., Kiyani, G. R. (2013). An investigation into the generaliziblity of quantitative research studies in Iranian ELT context. Language Related Research, 3(4), 206-228. Retrieved from http://lrr.modares.ac.ir/?_action=showPDF\&sc=1\&article=783\&_ob=3af5a5ea0353dc8fc9177cbf93fa1477\&fileName= full_text.pdf

Sarlak, N. \& Vafaeimehr, R. (2014). Iranian EFL teachers' reflection on current teacher training programs. International Journal of Language Learning and Applied Linguistics World (IJLLALW), 6(1), 47-58. Retrieved from www.ijllalw.org/finalversion615.pdf

Somekh, B. (2006). Action research: A methodology for change and development. Berkshire, England: Open University Press.

Talebinejad, M. \& Moattarian, A. (2015). Second language acquisition research and language pedagogy: A Critical view. International Journal of Linguistics, 7(4), 1-15. http://dx.doi.org/10.5296/ijl.v7i4.7826

Widdowson, H. G. (1990). Aspects of language teaching. Oxford: Oxford University Press. 